\title{
Budesonide suppresses pulmonary antibacterial host defense by down-regulating cathelicidin- related antimicrobial peptide in allergic inflammation mice and in lung epithelial cells
}

Peng Wang ${ }^{1,2+}$, Xiaoyun Wang ${ }^{1+}$, Xiaoqiong Yang ${ }^{3}$, Zhigang $\mathrm{Liu}^{4}$, Min Wu ${ }^{5}$ and Guoping $\mathrm{Li}^{1,4^{*}}$

\begin{abstract}
Background: Glucocorticoids are widely regarded as the most effective treatment for asthma. However, the direct impact of glucocorticoids on the innate immune system and antibacterial host defense during asthma remain unclear. Understanding the mechanisms underlying this process is critical to the clinical application of glucocorticoids for asthma therapy. After sensitization and challenge with ovalbumin (OVA), BALB/c mice were treated with inhaled budesonide and infected with Pseudomonas aeruginosa ( $P$. aeruginosa). The number of viable bacteria in enflamed lungs was evaluated, and levels of interleukin-4 (IL-4) and interferon- $\gamma$ (IFN- $\gamma$ ) in serum were measured. A lung epithelial cell line was pretreated with budesonide. Levels of cathelicidin-related antimicrobial peptide (CRAMP) were measured by immunohistochemistry and western blot analysis. Intracellular bacteria were observed in lung epithelial cells.
\end{abstract}

Results: Inhaled budesonide enhanced lung infection in allergic mice exposed to $P$. aeruginosa and increased the number of viable bacteria in lung tissue. Higher levels of IL-4 and lower levels of IFN- $\gamma$ were observed in the serum. Budesonide decreased the expression of CRAMP, increased the number of internalized P. aeruginosa in OVAchallenged mice and in lung epithelial cell lines. These data indicate that inhaled budesonide can suppress pulmonary antibacterial host defense by down-regulating CRAMP in allergic inflammation mice and in cells in vitro.

Conclusions: Inhaled budesonide suppressed pulmonary antibacterial host defense in an asthmatic mouse model and in lung epithelium cells in vitro. This effect was dependent on the down-regulation of CRAMP.

Keywords: Allergic airway inflammation, Antibacterial host defense, Cathelicidin, Budesonide

\section{Background}

Asthma is a chronic inflammatory disorder characterized by airway inflammation and airway hyperresponsiveness. Disease is mediated by increased levels of T-helper 2 (Th2) cytokines, interleukin (IL)-4, IL-5, and IL-13 and elevated serum IgE [1]. The lungs are always exposed to the environment and its microbial components. Infections

\footnotetext{
*Correspondence: Izlgp@163.com

${ }^{\dagger}$ Equal contributors

${ }^{1}$ Inflammations \& Allergic Diseases Research Unit, Affiliated Hospital of Luzhou Medical College, Luzhou, Sichuan 646000, China

${ }^{4}$ State Key Laboratory of Respiratory Disease for Allergy at Shenzhen University, School of Medicine, Shenzhen University, Nanhai Ave 3688, Shenzhen, Guangdong 518060, PR China

Full list of author information is available at the end of the article
}

of the respiratory tract are the most common diseases. Epidemiological investigations have indicated that allergic asthma is a risk factor for pulmonary infection [2,3]. Patients with atopic asthma also develop more infections than non-atopic individuals.

The innate immune system is the first line of host defense. It is responsible for the immediate recognition and regulation of microbial invasion. The innate immune system consists of a range of pre-existing, rapidly mobilized host cellular defenses, including neutrophils, macrophages, epithelial cells, mast cells, eosinophils, and natural killer cells [4]. Airway epithelial cells are an active part of the innate pulmonary immune system and are capable of recognizing microorganisms and secreting 
host defense molecules, including antimicrobial and antiviral proteins [5]. Antimicrobial peptides (AMPs) have significant antimicrobial activity. Cathelicidins are expressed in bone-marrow-derived and epithelial cells, and have antimicrobial action against bacteria, viruses, and fungi [6]. Low levels of cathelicidin expression can increase susceptibility to infections $[7,8]$. Th2 cytokines can inhibit antimicrobial host defense in individuals with allergic diseases, and treatment for atopic dermatitis with corticosteroids can cause a strong reduction in AMP levels in both human skin and essential-fatty-aciddeficient (EFAD) mice $[9,10]$.

Glucocorticoids, which are widely regarded as the most effective treatment for asthma, can inhibit the production of most cytokines [11]. In chronic obstructive pulmonary disease, inhaled corticosteroids can increase the risk of pneumonia [12]. Although glucocorticoids have a direct impact on the innate immune system, their effect on asthma remains unclear. To determine the effect of budesonide on antibacterial host defense and allergic airway inflammation, mice and a murine lung epithelial cell line (MLE-12) were treated with budesonide and infected with Pseudomonas aeruginosa. Our results show that inhaled budesonide suppressed pulmonary antibacterial host defense and this effect depended on the down-regulation of cathelicidin-related antimicrobial peptide (CRAMP).

\section{Results}

\section{Effects of budesonide on lung inflammation upon} exposure to $P$. aeruginosa

Inhaled budesonide inhibits allergic airway inflammation, but the mechanisms involved in increased risk of lung infection in asthmatic patients exposed to bacteria remains unclear. Twenty-four hours after the last dose of inhaled budesonide, histological analysis showed there was less inflammatory infiltration in OVA-challenged mice treated with budesonide (OVA/Bud) than in untreated OVA-challenged mice (OVA/No) (Figure 1B). The cellular infiltration scores of OVA/Bud mice were lower than those of OVA/No mice (Table 1).

This confirmed that inhaled budesonide inhibited allergic airway inflammation in OVA/Bud mice. However, we observed different results when mice were infected with $P$. aeruginosa. After treatment with inhaled budesonide, diffuse inflammatory cell infiltration and lung abscesses were observed in OVA-challenged mice exposed to $P$. aeruginosa (OVA/Bud/P.a). The cellular infiltration scores of OVA/Bud/P.a mice were higher than those for OVA-challenged mice exposed to $P$. aeruginosa (OVA/P.a).

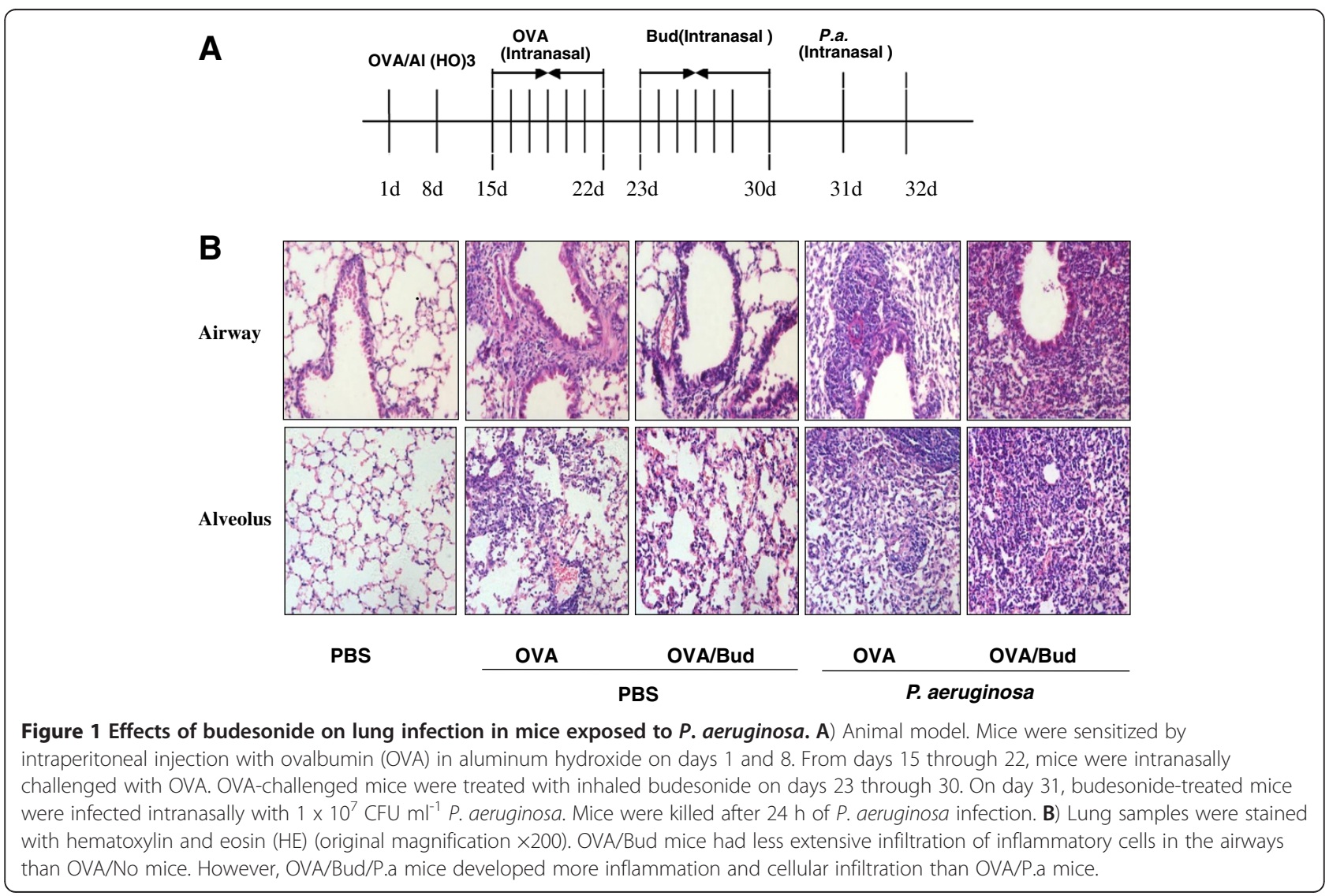


Table 1 The extent of lung inflammation were analyzed by microscopical histopathologic scoring $24 \mathrm{~h}$ after intrartracheal challenge with $P$. aeruginosa

\begin{tabular}{lcccc}
\hline Treatment group & No. of mice with the following lung pathology score/total no. of mice (\%) & \multicolumn{1}{c}{$\begin{array}{c}\text { Lungabscess incidence } \\
\text { (\%) }\end{array}$} \\
\cline { 2 - 4 } Control & $\mathbf{1 + 2}$ & $\mathbf{3}$ & 0 & 0 \\
OVA & $9 / 10(90)$ & $1 / 10(10)$ & $1 / 10(10)$ & 10 \\
OVA/P.a & $3 / 10(30)$ & $6 / 10(60)$ & $3 / 10(10)$ & 30 \\
ONA/BUD & 0 & $7 / 10(70)$ & 0 & 0 \\
OVA/BUD/P.a & $7 / 10(70)$ & $3 / 10(30)$ & $7 / 10(60)^{* *}$ & $70^{* *}$ \\
\hline
\end{tabular}

The cellular infiltration scoring of OVA/Bud mice was lower than that in OVA. The scoring of OVA/Bud/P. a mice was higher than that in OVA/P. a ${ }^{*} \mathrm{p}<0.001$ compared to OVA; ${ }^{* *} p<0.001$ compared to OVA/.a.

This indicated that $P$. aeruginosa infection increased lung inflammation in OVA-challenged mice treated with inhaled budesonide compared with untreated OVA-challenged mice.

Effects of budesonide on bacterial levels in OVAchallenged mice exposed to $P$. aeruginosa

To determine whether budesonide can increase the risk of pulmonary infection in asthma patients, bacterial levels in the lungs were determined $24 \mathrm{~h}$ after infection of mice with $P$. aeruginosa. Higher numbers of bacterial colony forming units (CFU) were observed in OVA/ Bud/P.a mice than in OVA/P.a mice $\left({ }^{*} P<0.05\right)$ (Figure 2). The number of CFU in control mice, which received phosphate-buffered saline (PBS) instead of active bacteria, was zero. These data show that inhaled budesonide can reduce the clearance of $P$. aeruginosa and increase pulmonary infection in OVA-challenged mice.

\section{Effects of budesonide on IL-4 in OVA-challenged mice exposed to $P$. aeruginosa}

Levels of IL-4 and interferon (IFN) $-\gamma$ in the serum of mice exposed to $P$. aeruginosa were detected to determine the relationship between inhaled budesonide and Th1/Th2 immunoreactions for antibacterial host defense during asthma. The levels of IL-4 in serum were lower in OVA/Bud mice compared with those in OVA/No mice $\left({ }^{*} P<0.01\right)$. However, the levels of IL- 4 in OVA/Bud/ P.a mice were higher than those in OVA/P.a mice $\left({ }^{\#} P<0.01\right)$. IL-4 levels were lower in PBS control mice (PBS) than in other mice (OVA/No, OVA/Bud and OVA/Bud/P.a mice) (Figure 3). The level of IFN- $\gamma$ in OVA/Bud mice was not significantly different from that of OVA/No mice (**P>0.05). There was also no significant difference between levels of IFN- $\gamma$ in OVA/Bud/P.a mice and OVA/P.a mice $\left({ }^{\# \#} P>0.05\right)$. IFN- $\gamma$ levels were lower in OVA/No, OVA/Bud, and OVA/Bud/P.a mice compared with those in PBS control mice (PBS) $(P<0.01)$ (Figure 3$)$. These data demonstrated that inhaled budesonide could decrease IL-4 levels in OVA- challenged mice and that $P$. aeruginosa infection could increase IL-4 levels in OVA/Bud/P.a mice.

Effects of budesonide on CRAMP in OVA-challenged mice exposed to $P$. aeruginosa

Airway epithelial cells can be induced to secrete AMPs. Whether inhaled budesonide can inhibit AMPs remains unclear. In the present study, AMP was expressed in epithelial cells of normal lungs and in epithelial cells and inflammatory cells in OVA-challenged mouse lung tissues (Figure 4A). CRAMP expression was significantly

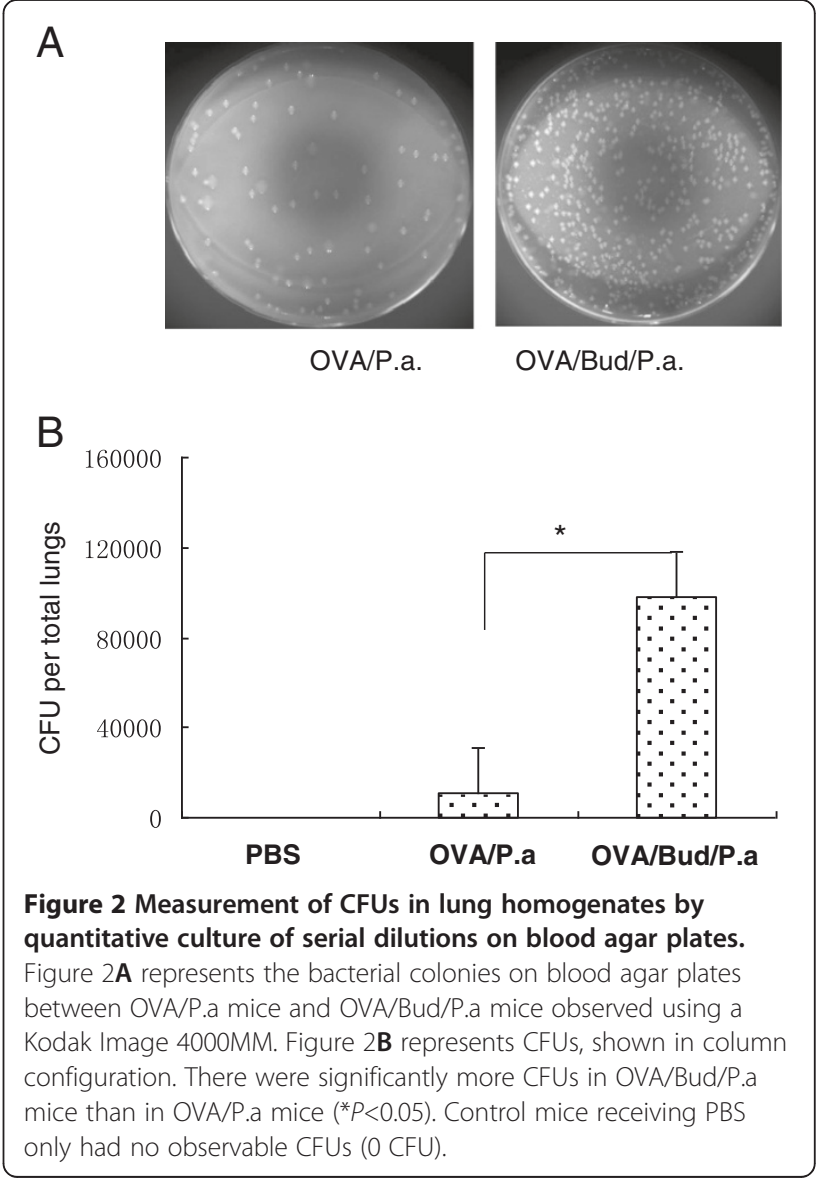



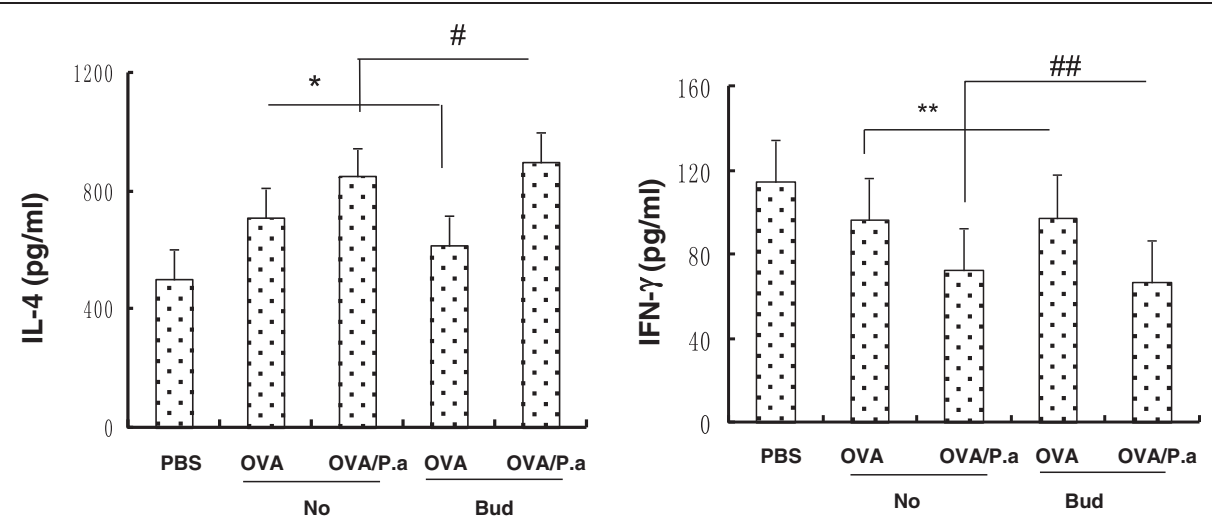

Figure 3 Serum levels of IL-4 and IFN-p. Cytokines in serum were determined by ELISA after $24 \mathrm{~h}$ of $P$. aeruginosa infection. IL-4 was lower in OVA/Bud mice than in OVA/No mice $\left({ }^{*} P<0.01\right)$. IL-4 in OVA/Bud/P.a mice was higher than in OVA/P.a mice $\left({ }^{\#} P<0.01\right)$. IFN- $\gamma$ in OVA/Bud mice was not significantly different from that of OVA/No mice $\left.{ }^{* *} P>0.05\right)$. IFN- $\gamma$ in OVA/Bud/P.a mice was not significantly different from that of OVA/P.a

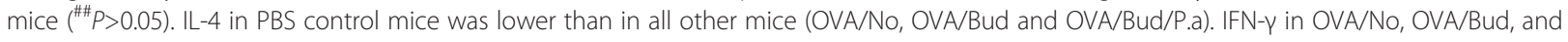
OVA/Bud/P.a mice was lower than in PBS control mice $(P<0.01)$.

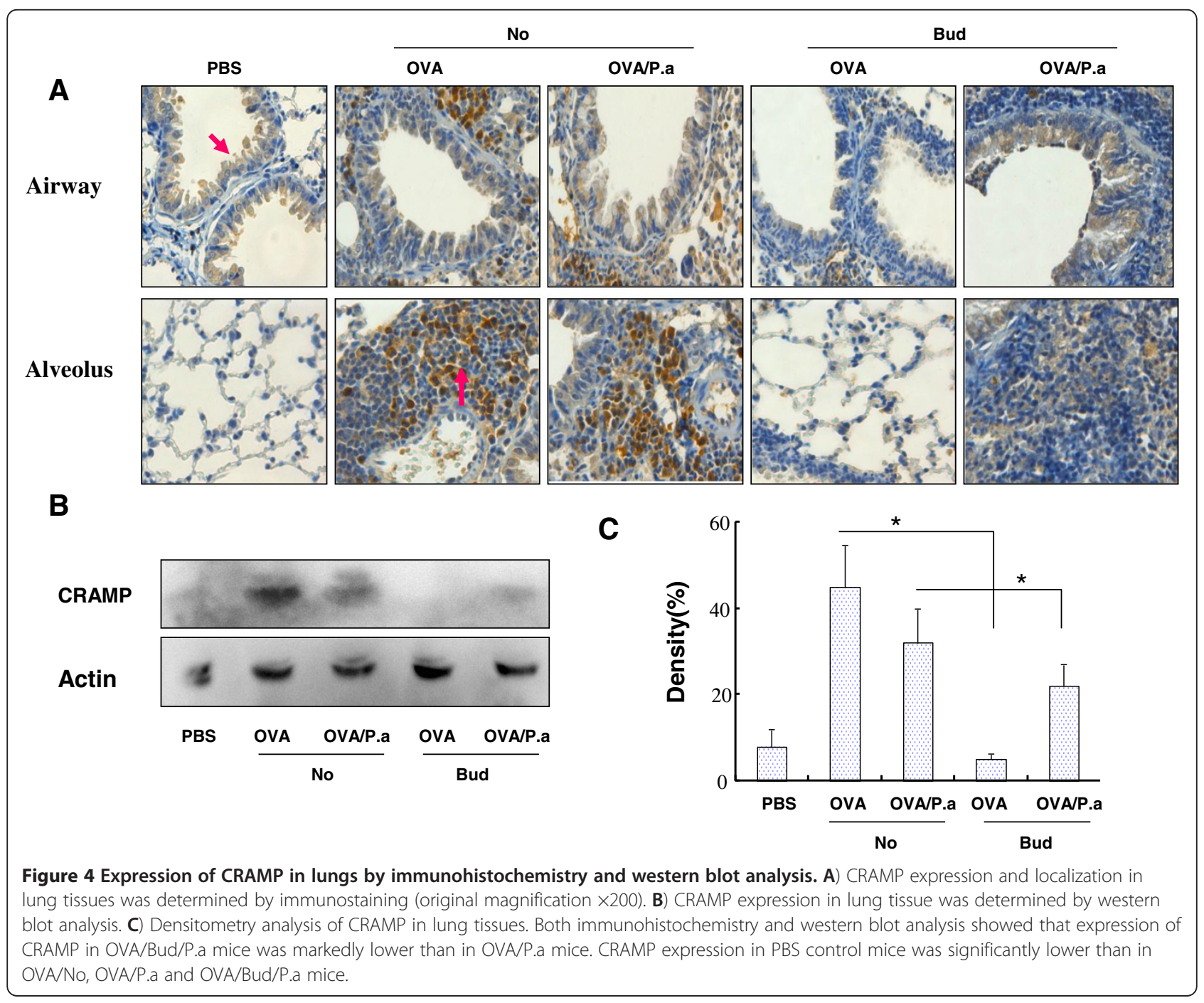


lower in PBS control mice (PBS) than in OVA/No, OVA/P.a, and OVA/Bud/P.a mice. This indicated that OVA and $P$. aeruginosa caused lung tissues to secrete AMPs. However, CRAMP expression was significantly lower in OVA/Bud mice than in OVA-challenged mice without inhaled budesonide (OVA/No mice). CRAMP expression was significantly lower in OVA/Bud/P.a mice than in OVA/P.a mice (Figure 4B). Thus, inhaled budesonide reduced the production of CRAMP during the antibacterial immune response to asthma.

\section{Effects of budesonide on the antibacterial host defense of} lung epithelial cells

Allergic airway inflammation suppresses the innate antimicrobial host defense [9]. However, whether inhaled budesonide can attenuate the antibacterial host defense in airway epithelial cells remains unclear. In our present studies, MLE-12 cells were pretreated with budesonide. We observed that budesonide increased the levels of internalized GFP-labeled $P$. aeruginosa in MLE-12 cells (Figure 5A). Total bacterial CFUs were significantly higher in MLE-12 cells exposed to budesonide than in those exposed to PBS. The effect of budesonide on bacterial CFUs in MLE-12 cells was dose-dependent (Figure $5 \mathrm{~B})$. High doses of budesonide $\left(10^{-6}\right.$ and $\left.10^{-7} \mathrm{M}\right)$ induced significantly lower levels of CRAMP compared with PBS or $10^{-8} \mathrm{M}$ budesonide $(P<0.01)$ (Figure $5 \mathrm{C}$ ). Thus, the role of CRAMP in antibacterial host defense may be interesting. Incubation of MLE-12 cells with CRAMPneutralizing antibody induced significantly higher levels of internalized GFP-labeled P. aeruginosa and bacterial CFUs than incubation with isotype IgG antibody (Figure 5D, E). This indicated that budesonide might attenuate the antibacterial host defense of airway epithelium cells by downregulating CRAMP (Figure 5F).

\section{Discussion}

Allergic asthma is a complex chronic inflammatory airway disease in which many immune cells such as mast cells, eosinophils, T lymphocytes, macrophages, neutrophils, and epithelial cells and cellular elements play different roles. The Th2 hypothesis for asthma was first proposed by Mosmann in 1989 [13]. He identified two different subtypes of $\mathrm{T}$ helper cells in mice namely Th1

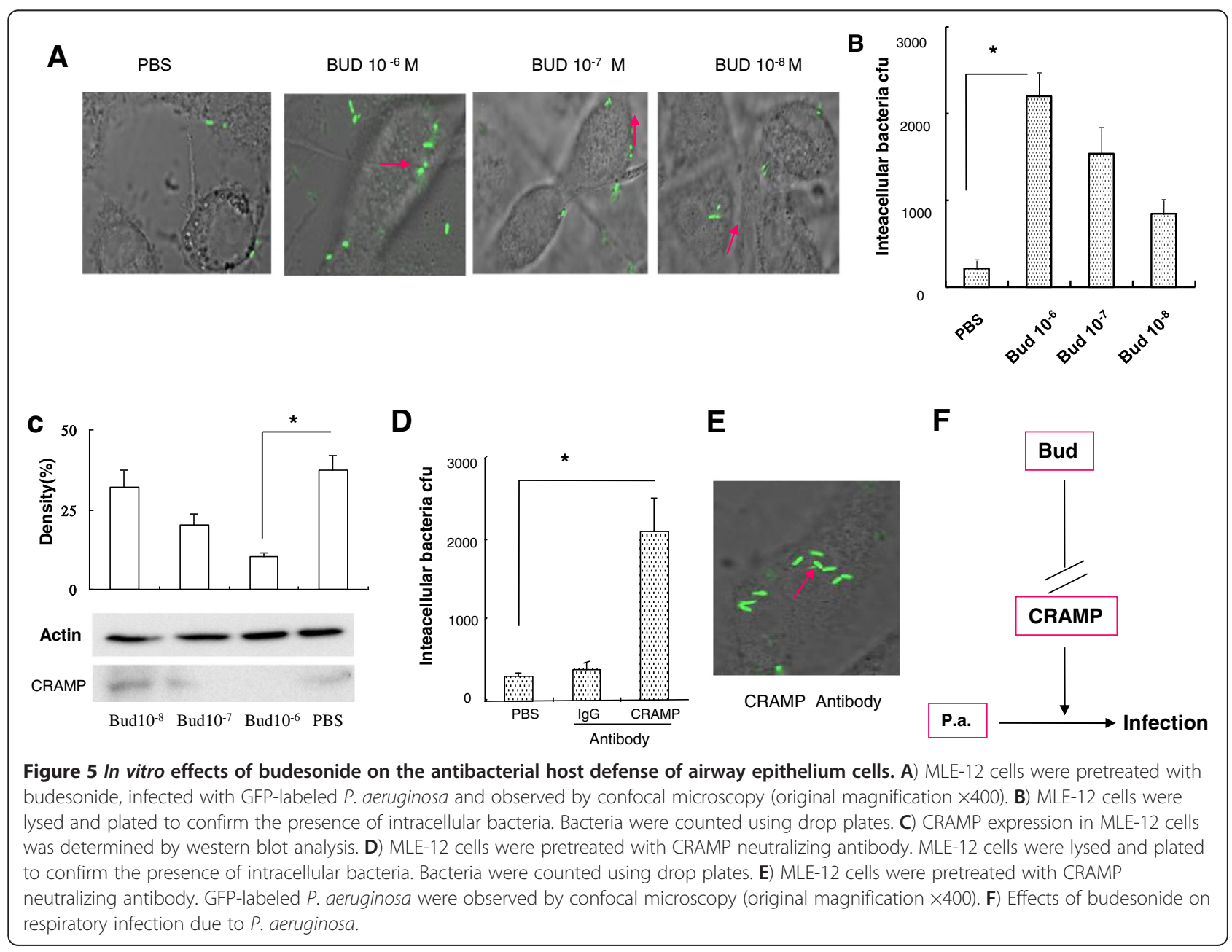


and Th2 [14] that produced a variety of cytokines and were reciprocally inhibitory. Th1 cells produce IFN- $\gamma$, IL-2 and IL-12, which activate mechanisms important for defense against viruses and bacteria [13]. Th2 cells produce cytokines (IL-4, IL-5, IL-6, IL-9, and IL-13), which are important in allergic inflammation and defense against parasites. The Th2 hypothesis of asthma suggests that an imbalance in Th1/Th2 immunity plays an important role in the pathogenesis of allergic asthma [15]. Inhaled corticosteroids (ICS) are recommended as a firstline treatment for asthma by international guidelines. However, a study conducted by Ma et al. showed that the early application of glucocorticoids was a risk factor for human enterovirus 71(HEV71) infection [16]. Recent studies have also shown that topical glucocorticoids compromise the barrier function of normal skin, especially during atopic dermatitis $[17,18]$. Jamieson et al. showed that a sustained increase in serum glucocorticoid levels in mice with influenza suppressed the systemic antibacterial innate immune response [19]. In the present study, inhaled budesonide decreased the extent of inflammation and cellular infiltration in the airways and the level of IL-4 in OVA-challenged mice. Because allergic airway tissues contain cytokines that promote bacterial infection and colonization in asthma and other lung diseases, Th2 cytokines may be relevant to infection in asthma patients [20]. However, OVA-challenged mice treated with inhaled budesonide and exposed to P. aeruginosa were characterized by the extensive infiltration of numerous inflammatory cells around bronchioles, alveoli, and blood vessels. This indicated that inhaled budesonide increased lung inflammation, reduced the clearance of $P$. aeruginosa, and increased the severity of pulmonary infection in OVAchallenged mice exposed to $P$. aeruginosa. Infection with $P$. aeruginosa was associated with increased levels of IL-4 in OVA-challenged mice treated with budesonide. Thus, our study indicated that inhaled budesonide increased lung infection in mice with allergic inflammation exposed to $P$. aeruginosa, independent of levels of IL-4.

Airway epithelial cells secrete numerous antimicrobial molecules that are part of the host's first line of defense against microbial invasion. Antimicrobial products secreted constitutively and/or inducibly by epithelial cells include lysozymes, lactoferrin, defensins, collectins, pentraxins, cathelicidin, secretory leukocyte protease inhibitor (SLPI), and serum amyloid A (SAA) [21]. Defensins and cathelicidins are primary AMP factors expressed in the lung and secreted by airway epithelial cells, macrophages, neutrophils, and other classical host defense cells. Another recent study demonstrated that IL-4 and IL-13 have an inhibitory effect on antimicrobial activity of the airway epithelium, as airway epithelial cells were unable to kill bacteria when incubated with these cytokines [6]. Mice with allergic airway inflammation showed significantly more viable bacteria in their lungs after infection. Th2-based inflammation was also found to suppress host defense and reduce AMP expression in the skin $[7,22]$. Thus, the adaptive immune system modulates the functions of the innate immune system and allergic inflammatory diseases inhibit antimicrobial host defense.

Inhaled corticosteroids are currently considered the most effective means of reducing airway inflammation, symptoms, and morbidity in patients with asthma. Glucocorticoids were shown to affect the synthesis of antimicrobial peptides in amphibian skin [23], inhibit NF- $\mathrm{kB}$ signaling and induce immunosuppression in mammalian cell cultures [24]. Mitchell et al. showed that bronchial biopsy specimens from dexamethasone-treated calves had significantly lower levels of tracheal antimicrobial peptide mRNA expression than untreated controls. Thus, corticosteroids may impair innate pulmonary defenses through the regulation of epithelial antimicrobial peptide expression [25]. Tomita et al. demonstrated that glucocorticoids inhibited the release of $\beta$-defensin- 2 stimulated by lipopolysaccharide in an airway cell line [26]. Aberg et al. showed that psychological stress and systemic and topical glucocorticoid therapy down-regulated epidermal antimicrobial peptide expression and increased the risk of extracutaneous infection in mice [27]. Roca-Ferrer et al. demonstrated that glucocorticoid treatment could cause a modest (30-40\%) inhibition of spontaneous lactoferrin secretion in cultured nasal and bronchial mucosa [28]. However, whether ICS can affect anti-microbial host defense among asthma patients remains unclear. In the present study, inhaled budesonide inhibited the production of CRAMP in the antibacterial immune response of OVAchallenged mice. AMP expression was localized to epithelial cells in normal lung tissues and expressed in epithelial cells and inflammatory cells in lung tissues of allergenchallenged mice. Thus, inhaled budesonide suppressed pulmonary antibacterial host defense in an asthmatic mouse model and was dependent on AMPs.

Inhaled corticosteroids induced candidiasis in clinical trials, but the association between the use of inhaled corticosteroids in patients with asthma and the risk of development of community-acquired pneumonia (CAP) remains controversial.

$P$. aeruginosa is the leading pathogenic cause of detrimental chronic lung infections, and is a major determinant of morbidity and mortality. Asthma patients with bronchiectasis are not rare, and their conditions are often exacerbated by $P$. aeruginosa status. Airway epithelial cells play a critical role in the orchestration of innate defense and inflammatory responses. $P$. aeruginosa can adhere to airway epithelial cells and internalization has been observed [29]. In the present study, budesonide increased the number of internalized $P$. aeruginosa organisms in MLE-12 cells in vitro. The effect of budesonide on bacteria CFU in MLE- 
12 cells was dose-dependent. High doses of budesonide significantly decreased CRAMP, which was associated with antibacterial host defense.

\section{Conclusions}

We showed that inhaled budesonide could increase the severity of $P$. aeruginosa infection in OVA-challenged mice and attenuate antibacterial host defense in airway epithelial cells by down-regulating CRAMP. These findings may have implications for glucocorticoid treatment of asthma patients.

\section{Methods}

\section{Materials}

BALB/c mice (weight 20 to $25 \mathrm{~g}$ and age 6 to 7 weeks) were purchased from the Experiment Animal Center of the Sichuan Academy of Medical Science. They were maintained under standard conditions. All animal experiments were performed in accordance with the guidelines of the affiliated hospital of Luzhou Medical College animal care and use committee. Pseudomonas aeruginosa strain $P$. aeruginosa 103 was provided by the clinical laboratory of the hospital affiliated with Lu Zhou Medical Collage. MLE-12 was maintained in our lab. P. aeruginosa labeled with green fluorescent protein (GFP) was provided by Dr. Min Wu of the University of North Dakota (US).

\section{Sensitization and challenge protocol}

$\mathrm{BALB} / \mathrm{c}$ mice were randomly grouped and sensitized with intraperitoneal injections of $20 \mu \mathrm{g}$ ovalbumin (OVA) in $50 \mu \mathrm{l}$ aluminum hydroxide on days 1 and 8 . Mice were challenged with intranasal instillation of $20 \mu \mathrm{g}$ OVA in $50 \mu \mathrm{l}$ phosphate-buffered saline (PBS) on days 15 through 22 inclusive. Control mice were given $50 \mu \mathrm{l} \mathrm{PBS}$.

\section{Acute $P$. aeruginosa pneumonia model}

OVA-challenged mice were treated with inhaled budesonide $(350 \mu \mathrm{g} / \mathrm{kg})$ for $30 \mathrm{~min}$ every day from day 23 through 30 as previously described [30]. Twenty-four hours after the last dose of inhaled budesonide and the last OVA challenge, OVA-challenged mice were anesthetized using diethyl ether. They were then infected intranasally with $1 \times 10^{7}$ CFUs $P$. aeruginosa [31]. Control mice received equivalent doses of PBS. Mice were euthanized 24 hours after infection (Figure 1A).

\section{Quantitation of bacteria}

The lungs were removed, weighed, and homogenized in $10 \%$ fetal bovine serum (FBS) in Dulbecco's modified Eagle's medium (DMEM), and aliquots were plated on $P$. aeruginosa-selective plates. Bacterial colonies were counted after incubation at $37^{\circ} \mathrm{C}$ for 24 hours, and images were obtained using a Kodak Image Station 4000MM (USA).

\section{Measurement of IL- 4 and IFN- $\gamma$ in serum}

The levels of serum IL-4 and IFN- $\gamma$ were determined using an ELISA kit (R\&D Systems, Minneapolis, MN, USA) in accordance with the manufacturer's instructions.

\section{Histopathological analysis}

Lung tissue was fixed in $4 \%$ paraformaldehyde for 24 hours at room temperature and embedded in paraffin. Five-micrometer serial sections were cut and stained with hematoxylin and eosin (HE) or subjected to immunostaining. They were then observed using light microscopy. The degree of cellular infiltration was scored using previously described methods [32]. Cellular infiltration was scored from 0 to 4 as follows: 0 normal cells; 1 few foci (minimal presence); 2 mild diffuse infiltration; 3 moderate diffuse infiltration; 4 severe diffuse infiltration.

\section{Immunohistochemistry}

The sections were deparaffinized and rehydrated. Endogenous peroxidase activity was blocked with $0.3 \%$ hydrogen peroxide and the sections were incubated at room temperature for $10 \mathrm{~min}$. Antigen retrieval was performed with citrate $(\mathrm{pH}=6)$ at $95^{\circ} \mathrm{C}$ in an aqueous bath. The process lasted $40 \mathrm{~min}$. The sections were incubated with rabbit polyclonal antibody against CRAMP (Abcam, Cambridge, MA, USA) at $37^{\circ} \mathrm{C}$ for $45 \mathrm{~min}$ (1:300). The secondary antibody (Envision ${ }^{\mathrm{TM}}$, DAKO, Denmark) was applied (1:500) and incubated at $37^{\circ} \mathrm{C}$ for $45 \mathrm{~min}$. Finally, the slides were visualized using DAB immunostaining under a light microscope (Leica, Solms, Germany).

\section{Preparation of $P$. aeruginosa for cell experiments}

GFP-labeled $P$. aeruginosa was incubated overnight in lysogeny broth (LB) culture medium on a shaking platform at $150 \mathrm{rpm}$. The bacteria were added to $10 \mathrm{ml}$ fresh LB medium and cultured for 1 hour until the mid-log phase. Optical density (OD) was measured at $600 \mathrm{~nm}$. When $\mathrm{OD}_{600 \mathrm{~nm}}$ reached 0.3 , the bacteria were centrifuged at $8000 \times g$ for 5 minutes at $4^{\circ} \mathrm{C}$. Bacteria were washed three times in sterile PBS and the density was adjusted to $0.1 \mathrm{OD}\left(0.1 \mathrm{OD}=1 \times 10^{8} \mathrm{cells} / \mathrm{ml}\right)$ in sterile Earle's salt solution. Cells were infected with $P$. aeruginosa at a 10:1 bacteria-cell ratio.

\section{Cell culture and infection experiments}

MLE-12 cells were incubated in 24-well tissue plates at $37^{\circ} \mathrm{C}$ and $5 \% \mathrm{CO}_{2}$ in DMEM/F12 culture medium. The cells were pretreated for 48 hours at $37^{\circ} \mathrm{C}$ with $10^{-6}, 10^{-7}$, and $10^{-8} \mathrm{M}$ budesonide until they reached $85 \%$ conflu-

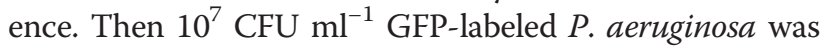
added to MLE-12 cells. For antibody treatment, MLE-12 
cells were grown in serum-free DMEM/F12 culture medium for 24 hours. Then $10 \mu \mathrm{g} / \mathrm{ml}$ of CRAMP antibody or a murine isotype control IgG was added to the cells and incubated for 1 hour. MLE-12 cells were infected with $10^{7} \mathrm{CFU} \mathrm{ml}{ }^{-1}$ GFP-labeled P. aeruginosa. After incubation for 1 hour, the cells were washed with PBS and incubated with fresh medium containing polymyxin $50 \mu \mathrm{g} \mathrm{ml}^{-1}$ to kill extracellular bacteria. After 1 hour, the culture media was removed and samples were plated in LB solid culture medium to confirm that the extracellular bacteria had been killed. The 24-well plates were observed using a Zeiss 510 META confocal microscope (Zeiss, Gottingen, Germany). The cells were then homogenized with PBS and spread on LB plates to determine levels of intracellular bacteria. The plates were cultured at $37^{\circ} \mathrm{C}$ overnight, and colonies were counted. Duplicates were made for each sample and control [33,34].

\section{Western blot}

Lung tissue and MLE-12 cells were homogenized in lysis buffer $(1000 \mu \mathrm{l}$ RIPA with $10 \mu \mathrm{l}$ phenylmethanesulfonylfluoride (PMSF), Beyotime, China). To ensure each sample contained equal amounts of protein, a protein assay was performed using a bicinchoninic acid (BCA) concentration measurement kit (Beyotime, China). Twenty micrograms of protein was loaded per lane and then run on $15 \%$ sodium dodecyl sulfate-polyacrylamide gel electrophoresis (SDS-PAGE) at $100 \mathrm{~V}$ for $90 \mathrm{~min}$. Dissolved proteins were transferred onto a nitrocellulose membrane by electroblotting with an Amersham Ecl Semi-Dry Transfer Unit ( $15 \mathrm{~V}$ for $20 \mathrm{~min}$ ). Non-specific binding sites were blocked with western confining liquid (Beyotime, China) at $37^{\circ} \mathrm{C}$ for 1 hour. Rabbit polyclonal antibody against CRAMP (1:500 dilution) was applied to the membranes and incubated overnight at $4^{\circ} \mathrm{C}$. The membranes were washed three times in PBS for 10 min each. They were then incubated with HRP-conjugated goat anti-rabbit antibody (1:800 dilution, Beyotime, China) at $37^{\circ} \mathrm{C}$ for 1.5 hours and washed three times for $10 \mathrm{~min}$ each. Chemiluminescent substrate (Beyotime, China) was added to the membrane and exposed strips were evaluated using a Kodak Image Station 4000MM (US).

\section{Statistical analysis}

Data are expressed as mean \pm standard error. Statistical analysis was performed using ANOVA (Tukey's post hoc) or Student's $t$-test and the level of significance was defined as $P<0.05$ between any two groups. The data were analyzed using SPSS 13.0 software.

\footnotetext{
Abbreviations

OVA: Ovalbumin; CRAMP: Cathelicidin-related antimicrobial peptide; AMPs: Antimicrobial peptides; MLE: Murine lung epithelial cell; GFP: Green fluorescence protein; ELISA: Enzyme-linked immunosorbent assay; HE: Hematoxylin and eosin; SDS-PAGE: Sodium dodecyl sulfate-
}

polyacrylamide gel electrophoresis; ANOVA: Analysis of variance; OVA/ Bud: OVA-challenged mice treated with budesonide; OVA/No: OVAchallenged mice without budesonide treatment; OVA/Bud/P.a: OVA challenged mice treated with budesonide and exposed to $P$. aeruginosa; OVA/P.a: OVA-challenged mice exposed to $P$. aeruginosa without budesonide treatment

\section{Competing interests}

The authors declare that they have no competing interests.

\section{Authors' contributions}

Conceived and designed the study: GL and ZL. Performed the experiment: PW, XW, GL, MW, and XY. Analyzed the data: PW. Contributed reagents and materials: MW. Wrote the paper: PW and XW. All authors read and approved the final manuscript.

\section{Acknowledgements}

This project was supported by the Chinese National Science Foundation (81170032) and Chinese Scholar Council.

\section{Author details}

${ }^{1}$ Inflammations \& Allergic Diseases Research Unit, Affiliated Hospital of Luzhou Medical College, Luzhou, Sichuan 646000, China. ${ }^{2}$ Bao Ji Central Hospital, Bao Ji, Shan Xi 721008, China. ${ }^{3}$ Department of Respiratory Disease, Affiliated Hospital of Luzhou Medical College, Luzhou 646000, China. ${ }^{4}$ State Key Laboratory of Respiratory Disease for Allergy at Shenzhen University, School of Medicine, Shenzhen University, Nanhai Ave 3688, Shenzhen, Guangdong 518060, PR China. ${ }^{5}$ Department of Biochemistry and Molecular Biology, University of North Dakota, 501 N Columbia Rd, EJRF Building Room 2726, Grand Forks, North Dakota 58203-9037, USA.

Received: 17 July 2012 Accepted: 4 February 2013

Published: 6 February 2013

\section{References}

1. Finn PW, Bigby TD: Innate immunity and asthma. Proc Am Thorac Soc 2009, 6(3):260-265.

2. Talbot TR, Hartert TV, Mitchel E, Halasa NB, Arbogast PG, Poehling KA, Schaffner W, Craig AS, Griffin MR: Asthma as a risk factor for invasive pneumococcal disease. N Eng J Med 2005, 352(20):2082-2090.

3. Jung JA, Kita H, Yawn BP, Boyce TG, Yoo KH, McGree ME, Weaver AL, Wollan $P$, Jacobson RM, Juhn YJ: Increased risk of serious pneumococcal disease in patients with atopic conditions other than asthma. J Allergy Clin Immunol 2010, 125(1):217-221.

4. Hoffmann JA, Kafatos FC, Janeway CA, Ezekowitz RA: Phylogenetic perspectives in innate immunity. Science 1999, 284(5418):1313-1318.

5. Bals R, Hiemstra PS: Innate immunity in the lung: how epithelial cells fight against respiratory pathogens. Eur Respir J: official journal of the European Society for Clinical Respiratory Physiology 2004, 23(2):327-333.

6. Zanetti M: The role of cathelicidins in the innate host defenses of mammals. Curr Issues Mol Biol 2005, 7(2):179-196.

7. Ong PY, Ohtake T, Brandt C, Strickland I, Boguniewicz M, Ganz T, Gallo RL, Leung DY: Endogenous antimicrobial peptides and skin infections in atopic dermatitis. N Eng J Med 2002, 347(15):1151-1160.

8. Chromek M, Slamova Z, Bergman P, Kovacs L, Podracka L, Ehren I, Hokfelt T, Gudmundsson GH, Gallo RL, Agerberth B, et al: The antimicrobial peptide cathelicidin protects the urinary tract against invasive bacterial infection. Nat Med 2006, 12(6):636-641.

9. Beisswenger C, Kandler K, Hess C, Garn H, Felgentreff K, Wegmann M, Renz $H$, Vogelmeier C, Bals R: Allergic airway inflammation inhibits pulmonary antibacterial host defense. J Immunol 2006, 177(3):1833-1837.

10. Jensen JM, Ahrens K, Meingassner J, Scherer A, Brautigam M, Stutz A, Schwarz T, Folster-Holst R, Harder J, Glaser R, et al: Differential suppression of epidermal antimicrobial protein expression in atopic dermatitis and in EFAD mice by pimecrolimus compared to corticosteroids. Exp Dermatol 2011, 20(10):783-788.

11. Barnes PJ: Anti-inflammatory therapy for asthma. Annu Rev Med 1993, 44:229-242.

12. Ernst $P$, Gonzalez AV, Brassard P, Suissa S: Inhaled corticosteroid use in chronic obstructive pulmonary disease and the risk of hospitalization for pneumonia. Am J Respir Crit Care Med 2007, 176(2):162-166. 
13. Mosmann TR, Coffman RL: TH1 and TH2 cells: different patterns of lymphokine secretion lead to different functional properties. Annu Rev Immunol 1989, 7:145-173.

14. Mosmann TR, Cherwinski H, Bond MW, Giedlin MA, Coffman RL: Two types of murine helper T cell clone. I. Definition according to profiles of lymphokine activities and secreted proteins. 1986. J Immunol 2005, 175(1):5-14.

15. Kay AB: The role of T lymphocytes in asthma. Chem Immunol Allergy 2006 , 91:59-75.

16. Ma H, He F, Wan J, Jin D, Zhu L, Liu X, Liu Q, Zhang G, Ding Z, Fontaine RE, et al: Glucocorticoid and pyrazolone treatment of acute fever is a risk factor for critical and life-threatening human enterovirus 71 infection during an outbreak in China, 2010. Pediatr Infect Dis J 2008, 29(6):524-529.

17. Choi EH, Demerjian M, Crumrine D, Brown BE, Mauro T, Elias PM, Feingold KR: Glucocorticoid blockade reverses psychological stress-induced abnormalities in epidermal structure and function. Am J Physiol Regul Integr Comp Physiol 2006, 291(6):R1657-1662.

18. Kao JS, Fluhr JW, Man MQ, Fowler AJ, Hachem JP, Crumrine D, Ahn SK, Brown BE, Elias PM, Feingold KR: Short-term glucocorticoid treatment compromises both permeability barrier homeostasis and stratum corneum integrity: inhibition of epidermal lipid synthesis accounts for functional abnormalities. J Invest Dermatol 2003, 120(3):456-464.

19. Jamieson AM, Yu S, Annicelli CH, Medzhitov R: Influenza virus-induced glucocorticoids compromise innate host defense against a secondary bacterial infection. Cell Host Microbe 2010, 7(2):103-114.

20. Nembrini C, Sichelstiel A, Kisielow J, Kurrer M, Kopf M, Marsland BJ: Bacterial-induced protection against allergic inflammation through a multicomponent immunoregulatory mechanism. Thorax 2011, 66(9):755-763.

21. Schleimer RP, Lane AP, Kim J: Innate and acquired immunity and epithelial cell function in chronic rhinosinusitis. Clin Allergy Immunol 2007, 20:51-78.

22. Nomura I, Goleva E, Howell MD, Hamid QA, Ong PY, Hall CF, Darst MA, Gao $B$, Boguniewicz M, Travers JB, et al: Cytokine milieu of atopic dermatitis, as compared to psoriasis, skin prevents induction of innate immune response genes. J Immunol 2003, 171(6):3262-3269.

23. Simmaco M, Boman A, Mangoni ML, Mignogna G, Miele R, Barra D, Boman HG: Effect of glucocorticoids on the synthesis of antimicrobial peptides in amphibian skin. FEBS Lett 1997, 416(3):273-275.

24. Scheinman RI, Cogswell PC, Lofquist AK, Baldwin AS Jr: Role of transcriptional activation of I kappa B alpha in mediation of immunosuppression by glucocorticoids. Science 1995, 270(5234):283-286.

25. Mitchell GB, Al-Haddawi MH, Clark ME, Beveridge JD, Caswell JL: Effect of corticosteroids and neuropeptides on the expression of defensins in bovine tracheal epithelial cells. Infect Immun 2007, 75(3):1325-1334.

26. Tomita T, Nagase T, Ohga E, Yamaguchi Y, Yoshizumi M, Ouchi Y: Molecular mechanisms underlying human beta-defensin-2 gene expression in a human airway cell line (LC2/ad). Respirology 2002, 7(4):305-310.

27. Aberg KM, Radek KA, Choi EH, Kim DK, Demerjian M, Hupe M, Kerbleski J, Gallo RL, Ganz T, Mauro T, et al: Psychological stress downregulates epidermal antimicrobial peptide expression and increases severity of cutaneous infections in mice. J Clin Invest 2007, 117(11):3339-3349.

28. Roca-Ferrer J, Mullol J, Perez M, Xaubet A, Molins L, de Haro J, Shelhamer J Picado C: Effects of topical glucocorticoids on in vitro lactoferrin glandular secretion: comparison between human upper and lower airways. J Allergy Clin Immunol 2000, 106(6):1053-1062.

29. Hawdon NA, Aval PS, Barnes RJ, Gravelle SK, Rosengren J, Khan S, Ciofu O, Johansen HK, Hoiby N, Ulanova M: Cellular responses of A549 alveolar epithelial cells to serially collected Pseudomonas aeruginosa from cystic fibrosis patients at different stages of pulmonary infection. FEMS Immunol Med Microbiol 2010, 59(2):207-220.

30. Shen H, O'Byrne PM, Ellis R, Wattie J, Tang C, Inman MD: The effects of intranasal budesonide on allergen-induced production of interleukin-5 and eotaxin, airways, blood, and bone marrow eosinophilia, and eosinophil progenitor expansion in sensitized mice. Am J Respir Crit Care Med 2002, 166(2):146-153.

31. Gadjeva M, Paradis-Bleau C, Priebe GP, Fichorova R, Pier GB: Caveolin-1 modifies the immunity to Pseudomonas aeruginosa. J Immunol 2010, 184(1):296-302.

32. Darville T, Andrews CW Jr, Laffoon KK, Shymasani W, Kishen LR, Rank RG: Mouse strain-dependent variation in the course and outcome of chlamydial genital tract infection is associated with differences in host response. Infect Immun 1997, 65(8):3065-3073.

33. Kannan S, Huang H, Seeger D, Audet A, Chen Y, Huang C, Gao H, Li S, Wu M: Alveolar epithelial type II cells activate alveolar macrophages and mitigate P. Aeruginosa infection. PLoS One 2009, 4(3):e4891.

34. Sana TG, Hachani A, Bucior I, Soscia C, Garvis S, Termine E, Engel J, Filloux A, Bleves S: The second type VI secretion system of Pseudomonas aeruginosa strain PAO1 is regulated by quorum sensing and Fur and modulates internalization in epithelial cells. J Biol Chem 2012, 287(32): 27095-27105.

doi:10.1186/1471-2172-14-7

Cite this article as: Wang et al:: Budesonide suppresses pulmonary antibacterial host defense by down-regulating cathelicidin-related antimicrobial peptide in allergic inflammation mice and in lung epithelial cells. BMC Immunology 2013 14:7.

\section{Submit your next manuscript to BioMed Central and take full advantage of:}

- Convenient online submission

- Thorough peer review

- No space constraints or color figure charges

- Immediate publication on acceptance

- Inclusion in PubMed, CAS, Scopus and Google Scholar

- Research which is freely available for redistribution

Submit your manuscript at www.biomedcentral.com/submit

C BioMed Central 